\title{
Associations between Leptin Gene Polymorphisms and Somatic Cell Count in Milk of Jersey Cows
}

\author{
Hanna Kulig, Marek Kmieć, Katarzyna Wojdak-Maksymiec \\ Westpomeranian University of Technology in Szczecin, Department of Genetics and Animal Breeding, \\ Szczecin, Poland \\ Received December 30, 2008 \\ Accepted December 3, 2009
}

\begin{abstract}
A total of 181 Jersey cows were used to investigate how leptin gene polymorphisms affect somatic cell count (SCC) in milk. Three single nucleotide polymorphisms were genotyped, namely the R4C polymorphism in exon 2, the Sau3AI polymorphism in intron 2 and the A59V polymorphism in exon 3 . The genotype and allele frequencies for each polymorphism and the haplotype frequencies for all polymorphisms were estimated in the herd under study. Statistical analysis revealed that the R4C and Sau3AI polymorphisms significantly affected SCC $(P \leq 0.01)$ with $C$ and $T$ as a desirable allele, respectively. No associations were found between the A59V polymorphism and SCC in this study. However, all the genotype combinations (haplotypes) significantly affected this trait. The results indicate that selection for the R4C CC and Sau3AI TT animals might contribute to a reduction of SCC in Jersey cattle.
\end{abstract}

Leptin, polymorphism, haplotype, somatic cell count, dairy cows, candidate gene, selection

Leptin is a $16-\mathrm{kDa}$ polypeptide hormone with a tertiary structure resembling that of some cytokines such as IL-6, IL-11, IL-12 and IL-15. It is produced primarily by fat cells but the presence of leptin was also demonstrated in the mammary gland tissue and in milk of different mammalian species (Zhang et al. 1994; Houseknecht et al. 1997; Estienne et al. 2000; Bonnet et al. 2002; McFadin et al. 2002). Leptin receptors are expressed in a variety of cells and tissues, including the immune cells. Leptin is mainly involved in maintaining the energy balance by controlling food intake and energy expenditure and it regulates the endocrine and immune functions (Houseknecht et al. 1998).

It has been established that leptin plays a major role in both innate and adaptive immune responses. Leptin mediates proliferative and antiapoptotic activities in the monocytes and T lymphocytes and delays apoptosis of neutrophils (Bruno et al. 2005). Leptin was found to promote $\mathrm{T}$ helper responses (Matarese et al. 2005) and also to regulate phagocytic function in macrophages/monocytes and secretion of proinflammatory cytokines (TNF- $\alpha$, IL-6, IL-12). Bernotiene et al. (2006) reported elevated circulating leptin level during infectious and inflammatory processes.

Mastitis - inflammation of the mammary gland - is a major cause of economic losses to the dairy cattle industry as it reduces milk yield, alters milk composition and elevates treatment costs. Mastitis is accompanied by an increased somatic cell count (SCC) in milk and estimated genetic correlation between mastitis and SCC ranges between 0.53 and 0.77 (Carlén et al. 2004; Ødegård et al. 2004; Koivula et al. 2005).

Therefore, SCC is a widely used indicator trait for mastitis, which in many countries is used as an indirect selection criterion for improving mastitis resistance (Interbull 2008). Monitoring and reducing SCC is the primary objective for dairy producers. However, it is necessary to keep within the physiological bounds.

Many studies have been conducted recently to search for candidate genes associated with udder health and immune processes and some genes have been proposed, for example: TNF- $\alpha$ - tumour necrosis factor $\alpha$, LTF - lactoferrin, DEF - defensin, CXCR - chemokine

Address for correspondence:

Dr. Hanna Kulig

Department of Genetics and Animal Breeding,

Westpomeranian University of Technology,

Phone/fax: +48 914541497

Doktora Judyma 6, 71-466 Szczecin, Poland

E-mail:Hanna.Kulig@zut.edu.p

http://www.vfu.cz/acta-vet/actavet.htm 
receptor, interleukin-8 (IL-8) receptor gene (Youngerman et al. 2004; Kamiński et al. 2006; Wojdak-Maksymiec et al. 2006). There have also been some reports on associations between leptin genotypes and SCC in dairy cattle (Buchanan et al. 2003). However, the majority of studies have been concerned with milk production, metabolic and/or reproductive traits in relation to leptin gene polymorphisms (Liefers et al. 2002; Liefers et al. 2005).

The aim of this study was to determine leptin allele and genotype frequencies and to establish possible associations between leptin gene polymorphisms (R4C, A59V, Sau3AI, and their combinations) and SCC in Jersey cows.

\section{Materials and Methods}

The study included a total of 181 Jersey cows kept on a farm located in the western region of Poland. All the animals were born of 17 sires between 1994 and 2001 and kept under identical management conditions: standard feeding, seasonal pasture feeding, and water available ad libitum.

The cows were milked twice a day with the use of a pipeline milking machine. Milk yield was evaluated with the A4 method in compliance with the recommendations of the International Committee for Animal Recording (ICAR). SCC data was recorded on the basis of monthly milking tests. SCC in the collected samples was determined with an instrumental method in compliance with the PN - EN ISO / IEC 17025 standard, using Combifoss equipment (including Fossmatic 5000 apparatus, Foss, Hillerod, Denmark). All the analyses were carried out in a certified milk analysis laboratory.

Blood from the external jugular vein was collected into tubes containing $\mathrm{K}_{3}$ EDTA. DNA was isolated with MasterPure kit (Epicentre ${ }^{\circledR}$ ) according to the manufacturer's instructions.

The analysed polymorphic sites are situated in:

1. the second exon; it is a $T / C$ transition which results in $\mathrm{R} 4 \mathrm{C}$ substitution in the protein;

2. the third exon; it is a $C / T$ transition which results in A59V substitution in the protein;

3. the second intron; it is a $C / T$ transition.

Genotype analyses were performed using the PCR-RFLP method. Amplification of the desired leptin gene fragments was performed with appropriate primer pairs with the following nucleotide sequences: 5'-ATGCGCTGTGGACCCCTGTAT-3' and 5'-TGGTG TCATCCTGGACCTTCC-3', a 94 bp (base pair) long fragment (R4C polymorphism) (Buchanan et al. 2002); 5'-GGGAAGGGCAGAAAGATAG-3' and 5'-TGGCAGACTGT TGAGGATC -3', a 331 bp long fragment (A59V polymorphism) (Haegeman et al. 2000); 5'-GTCACCAGGATCAATGACAT-3' and 5'-AGCCCAGGAATGAAGTCCAA-3', a 1820 bp long fragment (Sau3AI polymorphism) (Pomp et al. 1997).

The PCR was performed in a total volume of $20 \mathrm{ml}$ containing 50-100 ng DNA, $20 \mathrm{mM} \mathrm{Taq}$ polymerase buffer, $2 \mathrm{mM} \mathrm{MgCl}, 10$ pmol each primer, $200 \mathrm{mM}$ each dNTP, and $0.5 \mathrm{U}$ Taq DNA polymerase. The PCR products were digested with appropriate restriction enzymes: the $94 \mathrm{bp}$ fragment (R4C polymorphism) with $\mathrm{Kpn} 2 \mathrm{I}$ at $55^{\circ} \mathrm{C}$, the $331 \mathrm{bp}$ fragment (A59V polymorphism) with $\mathrm{HphI}$ at $37^{\circ} \mathrm{C}$ and the $1820 \mathrm{bp}$ fragment (Sau3AI polymorphism) with $\mathrm{Sau} 3 \mathrm{AI}$ at $37^{\circ} \mathrm{C}$. The obtained restriction fragments were separated on $3 \%$ and $2 \%$ agarose gels with ethidium bromide $(0.5 \mu \mathrm{g} / \mathrm{ml})$ in the presence of an appropriate DNA standard, and described using the Vilber Lourmat software for photodocumentation of electrophoretic separation and image storage.

The next stage involved a statistical analysis of associations between the leptin gene polymorphisms and SCC. Year/month of investigation, parity/month of lactation and cow (as a random factor nested within genotype) were also considered as sources of variability. SCC was transformed to the natural logarithm scale (ln SCC). SCC data was obtained from breeding documentation for 2001-2004. The statistical analysis of SCC in relation to leptin genotypes/haplotypes was carried out using the GLM (General Linear Model) multiple-factor mixed nested model (StatSoft 2006). The following linear model was applied:

(ln SCC) $y_{i j k l}=\mu+a_{i}+b_{j}+c_{k}+d_{l}\left(a_{i}\right)+e_{i j k l}$

where: $y_{i j k l}$ - somatic cell count (ln SCC); $\mu$-mean somatic cell count for herd (ln SCC); $a_{i}$ - effect of genotype/ haplotype $(i=1,2,3$ for R4C, A59V and Sau3AI; $i=1,2, \ldots, 6$ for R4C/A59V; $i=1,2, \ldots, 7$ for R4C/Sau3AI and A59V/Sau3AI); $b_{j}$ - effect of study year/month $(j=1,2, \ldots, 35) ; c_{k}-$ effect of parity/month of lactation $(k=$ $1,2, \ldots, 68) ; d_{l}\left(a_{i}\right)$ - effect of cow, random factor nested within leptin genotype $(l=1,2, \ldots, 181) ; e_{i j k l}-$ random error.

The differences between mean SCCs were verified with Duncan multiple range test.

\section{Results}

The frequencies of the analysed leptin genotypes and alleles as well as haplotypes are presented in Table 1.

Table 2 shows mean SCC values in cows with different leptin genotypes and haplotypes. Some haplotypes $(T T / C T, T T / T T)$ were not included in the statistical analysis due to their low 
Table 1. Frequencies of the leptin genotypes, alleles and haplotypes in Jersey cows

\begin{tabular}{|l|c|c|c|}
\hline \multirow{2}{*}{$\begin{array}{l}\text { Genotypes } \\
\text { alleles } \\
\text { haplotypes }\end{array}$} & \multicolumn{3}{|c|}{ Polymorphism } \\
\hline \multirow{3}{*}{$C C$} & $\mathrm{R} 4 \mathrm{C}$ & $\mathrm{A} 59 \mathrm{~V}$ & Sau3AI \\
\cline { 2 - 4 }$C T$ & 0.514 & 0.519 & 0.298 \\
$T T$ & 0.436 & 0.403 & 0.575 \\
$C$ & 0.050 & 0.078 & 0.127 \\
$T$ & 0.732 & 0.721 & 0.586 \\
\hline & 0.268 & 0.279 & 0.414 \\
$C C / C C$ & $\mathrm{R} 4 \mathrm{C} / \mathrm{A} 59 \mathrm{~V}$ & $\mathrm{R} 4 \mathrm{C} /$ Sau3AI & $\mathrm{A} 59 \mathrm{~V} /$ Sau3AI \\
\cline { 2 - 4 }$C C / C T$ & 0.199 & 0.105 & 0.110 \\
$C C / T T$ & 0.249 & 0.315 & 0.298 \\
$C T / C C$ & 0.066 & 0.094 & 0.110 \\
$C T / C T$ & 0.287 & 0.166 & 0.116 \\
$C T / T T$ & 0.138 & 0.248 & 0.271 \\
$T T / C C$ & 0.011 & 0.022 & 0.017 \\
$T T / C T$ & 0.033 & 0.028 & 0.072 \\
$T T / T T$ & 0.017 & 0.011 & 0.006 \\
\hline
\end{tabular}

number. The study results show significant $(P \leq 0.01, P \leq 0.05)$ differences between the mean SCC values in Jersey cows with different R4C and Sau3AI leptin genotypes as well as haplotypes (R4C/A59V, R4C/Sau3AI, A59V/Sau3AI).

The highest SCCs were found in the R4C TT cows. The difference between the $T T$ and $C C$ individuals averaged 0.899 ; the difference between the $T T$ and $C T$ cows was slightly lower (0.839). As regards the Sau3AI polymorphism, SCC was lower in the TT cows compared to the $C C$ and $C T$ genotype cows, by 0.408 and 0.333 , respectively. These results were confirmed by the $\mathrm{R} 4 \mathrm{C} / \mathrm{Sau} 3 \mathrm{AI}$ haplotype analysis. The $T T / C C$ haplotype individuals were characterised by a significantly higher SCC compared to the others.

No associations were found between the $\mathrm{A} 59 \mathrm{~V}$ polymorphism and the analysed trait in this study. It was found, however, that SCC was dependent on the A59V genotype in combination with the R4C and Sau3AIgenotypes. The R4C/A59V TT/CChaplotype cows were characterised by a significantly higher SCC compared to the individuals with other haplotypes. As regards the A59V/Sau3AI genotype combination, the $C T / T T$ haplotype cows were characterised by a significantly lower SCC compared to the cows with other haplotypes.

\section{Discussion}

Udder health has become an important dairy cattle breeding problem in many countries. Special attention is given to mastitis resistance.

Mastitis is a common and the most costly disease in dairy cattle. It is an inflammatory reaction of the mammary gland characterised by an influx of leukocytes (primarily polymorphonuclear neutrophils) from the blood into the milk as the cow's immune system responds to bacterial infection. Therefore, the concentration of somatic cells in milk increases (Rupp and Boichard 2003). Mastitis may occur in both clinical and sub-clinical forms. The first one is easily recognised due to visible changes in the udder (swelling, tenderness, hardness) and milk characteristics (flakes, clots). Sub-clinical infections are characterised by no visible signs of disease in both the udder and milk, although concentration of somatic cells in milk increases, milk production decreases and additionally milk composition may be changed. Moreover, high somatic cell concentration in milk is undesirable because it reduces the shelf-life of dairy products. The measure of somatic cell count (SCC) in milk reflects the incidence of both clinical and sub-clinical infections but monitoring SCC is particularly useful in diagnosis of sub-clinical mastitis when milk appears to be normal (Jones 1998; Petrovsky and Stefanov 2006).

Somatic cell concentration is genetically associated with mastitis. Genetic correlation between clinical mastitis incidence and SCC was estimated as moderate to high (Rupp and Boichard 2003). Moreover, it was estimated that SCC has a higher heritability than clinical mastitis (Lundt et al. 1994). This supports the use of SCC as an indirect indicator of udder health. 
Table 2. Means and standard deviations of somatic cell count (SCC) in cows with different leptin genotypes and haplotypes

\begin{tabular}{|c|c|c|c|}
\hline $\begin{array}{l}\text { Genotype } \\
\text { /haplotype }\end{array}$ & $\mathrm{N}$ & $\operatorname{lnSCC}$ & SD \\
\hline $\mathrm{R} 4 \mathrm{C}$ & & & \\
\hline$C C$ & 1420 & $5.153^{\mathrm{A}}$ & 1.143 \\
\hline$C T$ & 1062 & $5.213^{\mathrm{B}}$ & 1.172 \\
\hline$T T$ & 77 & $6.052^{\mathrm{AB}}$ & 1.116 \\
\hline A59V & & & \\
\hline$C C$ & 1186 & 5.162 & 1.149 \\
\hline$C T$ & 1137 & 5.269 & 1.193 \\
\hline$T T$ & 236 & 5.107 & 1.084 \\
\hline Sau3AI & & & \\
\hline$C C$ & 997 & $5.278^{\mathrm{A}}$ & 1.181 \\
\hline$C T$ & 1349 & $5.203^{\mathrm{B}}$ & 1.155 \\
\hline$T T$ & 213 & $4.870^{\mathrm{AB}}$ & 1.081 \\
\hline R4C/A59V & & & \\
\hline$C C / C C$ & 481 & $5.066^{\mathrm{A}}$ & 1.155 \\
\hline$C C / C T$ & 715 & $5.216^{\mathrm{B}}$ & 1.151 \\
\hline$C C / T T$ & 224 & $5.139^{\mathrm{C}}$ & 1.082 \\
\hline$C T / C C$ & 628 & $5.127^{\mathrm{D}}$ & 1.104 \\
\hline$C T / C T$ & 422 & $5.360^{\mathrm{E}}$ & 1.256 \\
\hline$T T / C C$ & 77 & $6.052^{\mathrm{ABCDE}}$ & 1.116 \\
\hline R4C/Sau3AI & & & \\
\hline$C C / C C$ & 397 & $5.154^{\mathrm{A}}$ & 1.109 \\
\hline$C C / C T$ & 835 & $5.221^{\mathrm{Bg}}$ & 1.164 \\
\hline$C C / T T$ & 188 & $4.850^{\mathrm{Cgh}}$ & 1.078 \\
\hline$C T / C C$ & 523 & $5.258^{\mathrm{Dh}}$ & 1.204 \\
\hline$C T / C T$ & 514 & $5.176^{\mathrm{E}}$ & 1.142 \\
\hline$C T / T T$ & 25 & $5.019^{\mathrm{F}}$ & 1.109 \\
\hline$T T / C C$ & 77 & $6.052^{\mathrm{ABCDEF}}$ & 1.116 \\
\hline A59V/Sau3AI & & & \\
\hline$C C / C C$ & 333 & $5.235^{\mathrm{A}}$ & 1.181 \\
\hline$C C / C T$ & 677 & $5.188^{\mathrm{B}}$ & 1.136 \\
\hline$C C / T T$ & 176 & 4.927 & 1.116 \\
\hline$C T / C C$ & 440 & $5.381^{\mathrm{C}}$ & 1.223 \\
\hline$C T / C T$ & 660 & $5.232^{\mathrm{D}}$ & 1.175 \\
\hline$C T / T T$ & 37 & $4.596^{\mathrm{ABCDE}}$ & 0.857 \\
\hline$T T / C C$ & 224 & $5.139^{\mathrm{E}}$ & 1.082 \\
\hline
\end{tabular}

$\mathrm{N}$ - numbers of observation

The means in columns marked with the same superscript letter differ significantly. Capital letters denote significance of difference at $P \leq 0.01$, whereas small letters denote significance of difference at $P \leq 0.05$.
Currently, the selection strategies for mastitis resistance are based on SCC which is routinely recorded in most dairy cattle recording systems. The direct information on clinical mastitis is usually not available, except for Scandinavian countries where selection for udder health is also based on mastitis incidence (Heringstad et al. 2000). Nevertheless, SCC is considered a good alternative for mastitis data.

Identification of genetic markers associated with SCC might be helpful in improving cows' health by implementing appropriate cattle-breeding programmes. Moreover, it might improve milk production traits as a healthy udder is the most important factor responsible for milk yield and quality (Jones 1998).

There are some promising mastitis-associated candidate genes, which play a particularly importantrole in the immunological functions of the mammary gland. One of these candidates is the gene encoding lactoferrin (LTF), which is synthesized by granulocytes and mammary epithelial cells in response to bacterial infection. Lactoferrin gene polymorphisms were found to be associated with SCC in Polish Holstein-Friesian cows (Kamiński et al. 2006; Wojdak-Maksymiec et al. 2006). The candidate genes also include the interleukin-8-receptor (IL-8-R) gene, which is essential for neutrophil migration to the mammary gland and infection resolution. The preliminary results reported by Youngerman et al.

(2003) support the hypothesis that some IL-8-R gene polymorphisms are associated with mastitis resistance in dairy cows. Other possible genetic markers for mastitis involved in the neutrophil function are the chemokine receptors present on the neutrophil surface, CRCX1 and CRCX2. The three polymorphisms identified within the CXCR2 gene were associated with sub-clinical mastitis in Jersey cows (Youngerman et al. 2004). Most studies concern genes encoding MHC (major histocompatibility complex) molecules, which play 
an essential role in the induction and regulation of the acquired immune response. Some of class I alleles were associated with mastitis traits (resistance or susceptibility); more specifically, alleles $A 11$ and $A 12$ were associated with a decreased SCC, whilst $A 21$ and $A 26$ - with an increased SCC. Among class II genes, DRB3 locus was extensively analysed because of its high polymorphism and the DRB3.2*24 allele was associated with a higher SCC (Rupp and Boichard 2003).

Due to the role of leptin in the immune response, the gene encoding it may be regarded as a candidate gene for udder health. Including the leptin gene polymorphisms in association study with SCC appears interesting, since SCC is often used in selection for udder health when direct information on clinical mastitis is not available.

The results of this study show that the R4C and Sau3AI leptin genotypes as well as their combinations (haplotypes) significantly affect SCC in Jersey cattle. The R4C TT genotype individuals were characterised by the highest SCC whereas the Sau3AI TT cows were characterised by the lowest SCC. No associations were found between the A59V polymorphism and the trait analysed in this study. Similarly, Buchanan et al. (2003) found that the homozygous R4C TT cows were characterised by a significantly higher SCC linear score compared with the $C T$ and $C C$ individuals. There are no reports concerning the other SNPs analysed here.

The results of this study could be of economic advantage to dairy producers. They suggest that if breeding programmes are based upon the leptin gene polymorphisms, preference towards cows with the R4C CT or CC genotypes, as well as Sau3AI TT genotype might contribute to a decreased SCC in Jersey cattle.

It should be remembered that excessive decreasing SCC in milk may reduce immunity; it was reported that too low SCC $(<200,000$ cells $/ \mathrm{ml})$ in milk of healthy cows increased the risk of clinical mastitis after contact with a pathogenic factor (Suriyasathaporn et al. 2000). That is why selection focused on SCC decreasing should be applied very thoughtfully.

Further research on associations between leptin genotypes and SCC in dairy cattle is necessary before the presented results are used in selection programmes. Moreover, it would be better to include a larger population in future studies and, if possible, to add information about clinical mastitis. It would increase the efficiency of selection for udder health, and therefore for milk quality.

\section{Acknowledgments}

This work was financially supported by the Agricultural University of Szczecin - project no. BW/IB/15/2004.

\section{References}

Bernotiene E, Palmer G, Gabay C 2006: The role of leptin in innate and adaptive immune responses. Arthritis Res Ther 8: 217-226

Bonnet M, Delavaud C, Laud K, Gourdou I, Leroux C, Djiane J, Chilliard Y. 2002: Mammary leptin synthesis, milk leptin and their putative physiological roles. Reprod Nutr Dev 42: 399-413

Bruno A, Conus S, Schmid I, Simon H-U 2005: Apoptotic pathways are inhibited by leptin receptor activation in neutrophils. J Immunol 174: 8090-8096

Buchanan FC, Van Kessel AG, Waldner C, Christensen DA, Laarveld B, Schmutz SM 2003: Hot Topic: An association between a leptin single nucleotide polymorphism and milk and protein yield. J Dairy Sci 86: 3164-3166

Carlén E, Strandberg E, Roth A 2004: Genetic parameters for clinical mastitis, somatic cell score, and production in the first three lactations of Swedish Holstein cows. J Dairy Sci 87: 3062-3070

Estienne MJ, Harper AF, Kozink DM, Knight JW 2003: Serum and milk concentrations of leptin in gilts fed a high- or low-energy diet during gestation. Anim Reprod Sci 75: 95-105

Haegeman A, Van Zeveren A, Peelman LJ 2000: New mutation in exon 2 of the bovine leptin gene. Anim Genet 31: 79

Houseknecht KL, Baile CA, Matteri RL, Spurlock ME 1998: The biology of leptin: a review. J Anim Sci 76: $1405-1420$ 
Houseknecht KL, McGuire MK, Portocarrero CP, McGuire MA, Beerman K 1997: Leptin is present in human milk and is related to maternal plasma leptin concentration and adiposity. Biochem Biophys Res Commun 240: $742-747$

Interbull 2008: Description of national genetic evaluation systems for dairy cattle traits as applied in different Interbull member countries. http://www.interbull.slu.se/national ges info2/framesida-ges.htm

Jones GM 1998: Guidelines for using the DHI somatic cell count program. http://www.ext.vt.edu/pubs/ dairy/404-228/404-228.html

Kamiński S, Oleński K Brym P, Malewski T Sazanov AA 2006: Single Nucleotide Polymorphism in the promoter region of the lactoferrin gene and its associations with milk performance traits in Polish Holstein-Friesian cows. Russ J Genet 42: 924-927

Koivula M, Mäntysaari EA, Negussie E, Serenius T 2005: Genetic and phenotypic relationships among milk yield and somatic cell count before and after clinical mastitis. J Dairy Sci 88: 827-833

Liefers SC, te Pas MFW, Veerkamp RF, van der Lende T 2002: Associations between leptin gene polymorphisms and production, live weight, energy balance, feed intake, and fertility in Holstein heifers. J Dairy Sci 85: 16331638

Liefers SC, Veerkamp RF, te Pas MF, Delavaud C, Chilliard Y, Platje M, van der Lende T 2005: Leptin promoter mutations affect leptin levels and performance traits in dairy cows. Anim Genet 36: 111-118

Lund T, Miglior F, Dekkers JCM, Burnside EB 1994: Genetic relationships between clinical mastitis, somatic cell count, and udder conformation in Danish Holsteins Liv Prod Sci 39: 243-251

Matarese G, Moschos S, Mantzoros CS 2005: Leptin in immunology. The J Immunol 173: 3137-3142

McFadin EL, Morrison CD, Buff PR, Whitley NC, Keisler DH 2002: Leptin concentrations in periparturient ewes and their subsequent offspring. J Anim Sci 80: 738-43

Ødegård J, Heringstad B, Klemetsdal G 2004: Short communication: Bivariate genetic analysis of clinical mastitis and somatic cell count in Norwegian dairy cattle. J Dairy Sci 87: 3515-3517

Petrovsky K, Stefanov E 2006: Milk composition changes during mastitis. http://www.milkproduction.com/ Library/Articles/Milk_composition_changes_during_mastitis.htm

Pomp D, Zou T, Clutter AC, Barendse W 1997: Rapid communication: Mapping of leptin to bovine chromosome 4 by linkage analysis of a PCR-based polymorphism. J Anim Sci 75: 1427

Rupp R, Boichard D 2003: Genetics of resistance to mastitis in dairy cattle. Vet Res 34: 671-688

Statistica (data analysis software system), version 7.1., (2006), StatSoft Poland

Suriyasathaporn W, Schukken YH, Nielen M, Brand A 2000: Low somatic cell count: a risk factor subsequent clinical mastitis in a dairy herd. J Dairy Sci 83: 1245-1255

Wojdak-Maksymiec K, Kmieć M, Ziemak J 2006: Associations between bovine lactoferrin gene polymorphism and somatic cell count in milk. Vet Med 51: 14-20

Youngerman SM, Oliver SP, Saxton AM, Edwards JL, Schrick FN, Davies CJ, Pighetti GM 2003: Interleukin-8 Receptor: a promising candidate gene for mastitis resistance. Annual Meeting-National Mastitis Council Inc 42: 358-359

Youngerman SM, Saxton AM, Oliver SP, Pighetti GM 2004: Association of CXCR2 polymorphisms with subclinical and clinical mastitis in dairy cattle. J Dairy Sci 87: 2442-2448

Zhang Y, Proenca R, Maffei M, Barone M, Leopold L, Friedman JM 1994: Positional cloning of the mouse obese gene and its human homologue. Nature 372: 425-432 